\title{
Gaya Hidup Mahasiswa Akibat Adanya Online Shop
}

\author{
Noor Fatmawati \\ noorfatmawati64@yahoo.com \\ Intitut Agama Islam Negeri Kudus
}

\author{
Submitted \\ Maret 23, 2020
}

\begin{tabular}{cc} 
Revised & $\begin{array}{c}\text { Accepted } \\
\text { June 23, 2020 }\end{array}$ \\
June 23, 2020 \\
https://dx.doi.org/ 10.17509/jpis.v29i1.23722 & \\
\hline
\end{tabular}

\section{ABSTRACT}

Internet technology that offers online shop services has changed the lifestyle of students, especially students of the IAIN Kudus. This study aims to determine the lifestyle of the IAIN Kudus students due to the existence of an online shop and analyze the factors underlying the students making purchases through an online shop. This study uses a qualitative. The results showed that the online shop had changed the lifestyle of students into consumptive behavior. Students who have consumptive lifestyles always look attractive, wear branded fashion, have middle to high living standards, and get along with people who have similar hobbies. In line with the theory of consumption society which shows that they consume goods because of the development of modern times through the use of online shop services. Factors that influence the use of online shop are time efficiency, supportive access, and fulfillment of goods needs and satisfaction. Fulfillment of satisfaction can be seen from the selection of branded goods to be seen to exist in their social environment. Therefore, we need to consider what you want to buy through online shop services, so that consumptive behavior can be avoided.

Keywords: lifestyle, online shop, consumptive.

\begin{abstract}
ABSTRAK
Teknologi internet yang menawarkan jasa online shop telah mengubah gaya hidup mahasiswa, khususunya mahasiswa IAIN Kudus. Penelitian ini bertujuan untuk mengetahui gaya hidup mahasiswa IAIN Kudus akibat adanya online shop dan menganalisis faktor-faktor yang melatarbelakngi mahasiswa melakukan pembelian melalui online shop. Penelitian ini menggunakan pendekatan kualitatif. Hasil penelitian menunjukkan bahwa online shop telah merubah gaya hidup mahasiswa menjadi berperilaku konsumtif. Mahasiswa yang memiliki gaya hidup konsumtif selalu berpenampilan menarik, mengenakan fashion bermerk, memiliki standar hidup menengah ke atas, serta lebih banyak bergaul dengan orang-orang yang memiliki hobi sama. Searah juga dengan teori masyarakat konsumsi yang memperlihatkan bahwa mereka mengkonsumsi barang karena perkembangan zaman modern melalui pemakaian jasa online shop. Faktor yang mempengaruhi pemanfaatan online shop adalah efisiensi waktu, akses yang mendukung, serta sebagai pemenuhan kebutuhan barang dan kepuasan. Pemenuhan kepuasan terlihat dari pemilihan barang bermerk untuk terlihat eksis di lingkungan sosialnya. Oleh karena itu, kita perlu mepertimbangkan apa yang ingin dibeli melalui jasa online shop, sehingga perilaku konsumtif dapat dihindari.
\end{abstract}

Keywords: gaya hidup, online shop, konsumtif

\section{PENDAHULUAN}

Perkembangan teknologi dan informasi memberikan perubahan yang nyata di segala aspek kehidupan masyarakat. Salah satunya adalah teknologi internet yang memberikan 
banyak kemudahan dalam berkomunikasi yang telah mampu mengubah perilaku masyarakat, khususunya masyarakat Indonesia. [1] mempublikasikan bahwa active user (pengguna aktif internet) di Indonesia tahun 2019 meningkat sebanyak 150 juta penduduk dari 143 juta di tahun 2018.

Perubahan perilaku masyarakat Indonesia dapat diketahui dari penggunaan internet yang dijelaskan sebelumnya, bahwa masyarakat yang semula tidak aktif menggunakan internet menjadi aktif sebagai pengguna internet. Hal ini memperlihatkan kebiasaan perilaku masyarakat Indonesia yang lebih memanfaatkan waktunya untuk menggunakan internet sebagai salah satu aktivitas sehari-hari, bahkan sebagai alat untuk memenuhi kebutuhan sosialnya. Artinya, secara langsung teknologi memberikan dampak perubahan sosial bagi masyarakat Indonesia melalui penggunaan internet. Selain itu, penggunaan internet juga mengalami perubahan dari segi pemanfaatannya.

Berdasarkan [2] menyatakan bahwa penggunaan internet yang semula cenderung untuk komunikasi pemasaran dan pencitraan, kini sebagian sudah menggunakannya sebagai transaksi pembelian. Transaksi pembelian dalam internet biasa kita sebut dengan online shopping. Hanya perlu terhubung dengan internet untuk melakukan transaksi jual beli secara online, berbelanja jadi lebih mudah dan hemat waktu. Aspek kepraktisan ini mengakibatkan para konsumen tertarik untuk berbelanja melalui internet, khususnya masyarakat Indonesia.

\section{Menteri Komunikasi dan} Informatika, [3] melalui akun Twiter-nya (2016) menyebutkan bahwa pada 2016 ada 8,7 juta konsumen toko online, jumlah tersebut naik dari tahun sebelumnya yang hanya sebesar 7,4 juta pembelanja online. Diakui atau tidak, hal ini perlahan-lahan mulai mengubah gaya hidup masyarakat.

Gaya hidup merupakan cara hidup seseorang untuk menghabiskan waktu (aktivitas) yang mereka anggap penting dalam lingkungannya, dan apa yang mereka pikirkan tentang diri mereka sendiri dan lingkungan sekitarnya [4]. Cara hidup yang dilakukan setiap masyarakat biasanya berbeda-beda bergantung pada aktivitasnya sehari-hari, baik karena kebutuhan maupun pengaruh lingkungan sekitar yang meliputi: keluarga, pekerjaan, komunitas, bisnis, politik, pendidikan, dan masa depan.

Pada setiap kesempatan aktivitas seseorang, online shopping menjadi perbincangan oleh sebagian kalangan mahasiswa. Mereka cenderung memiliki ketertarikan dengan produk-produk online shop untuk menjaga penampilan sebagai wujud identitas diri [5] Hal ini dikarenakan belanja online memiliki manfaat tersendiri bagi konsumennya yaitu hemat, baik hemat waktu, biaya, maupun tenaga, serta terjamin kualitas barangnya.

Pernyataan tersebut diperjelas oleh penelitian [6] yang menunjukkan bahwa sebagian besar mahasiswa ingin memenuhi kebutuhan hidupnya dengan cara instan tanpa harus membuang banyak tenaga dan waktu, serta harga yang ditawarkan di toko online tidak terlalu mahal. Sejalan juga dengan penelitian yang dilakukan oleh [7] bahwa faktor-faktor yang melatarbelakangi mahasiswa Akbid Wira Husada Nusantara Malang melakukan pembelian melalui online shop yaitu karena faktor waktu dan tempat yang fleksibel, harga disesuaikan dengan kualitas produk, 
mudah melakukan transaksi tanpa harus mendatangi toko langsung, pilihan jenis lebih banyak, dan kenyamanan dalam memilih produk.

Meskipun banyak manfaat yang didapat dari pembelian melalui online shop, namun munculnya online shop ini menimbulkan perubahan gaya hidup pada mahasiswa. Salah satunya adalah perilaku konsumtif, mereka belanja lewat online bukan karena kebutuhan lagi tetapi agar terlihat fashionable [8]. Selain itu, orang-orang konsumtif saat membeli produk memilih yang bermerk agar eksistensinya dapat diterima [9].

Perilaku konsumtif pada pemilihan barang menunjukkan adanya pengaruh modernisasi, di mana fungsi barang diabaikan dan trend barang menjadi pertimbangan utama dalam pemilihannya [10]. Perilaku konsumtif yang terjadi di kalangan mahasiswa ini sesuai dengan hasil penelitian yang ditemukan oleh [11] bahwa terdapat bentuk perilaku konsumtif yang dialami mahasiswa Fakultas IImu Sosial dan Hukum, UNESA yang dapat ditunjukkan dari faktor-faktor yang mendorong mereka dalam memilih berbelanja secara online yaitu tanpa adanya pertimbangan yang mengarah pada faktor kebutuhan (nilai guna) dan justru lebih mengarah pada faktor prestige (nilai tanda).

Kegiatan belanja secara online ini menjadi hal keseharian dan dapat dikatakan sebuah gaya hidup konsumtif karena sudah biasa dilakukan, bahkan dilakukan secara terus menerus, berkelanjutan, dan menjadi ketergantungan[12].

Fenomena online shopping juga terlihat pada mahasiswa Institut Agama Islam Negeri Kudus (IAIN Kudus) karena banyak dari mereka yang melakukan pembelian barang melalui online shop. Oleh karena itu, penulis merumuskan masalah yaitu: bagaimana gaya hidup mahasiswa IAIN Kudus akibat adanya online shop dan apa saja faktor-faktor yang melatarbelakangi mahasiswa IAIN Kudus melakukan pembelian melalui online shop. Adapun tujuan penlitian ini adalah untuk mengetahui gaya hidup mahasiswa IAIN Kudus akibat adanya online shop dan untuk menganalisis faktor-faktor yang melatarbelakngi mahasiswa IAIN Kudus melakukan pembelian melalui online shop.

\section{KAJIAN LITERATUR}

\section{Teori Strukturasi}

Teori strukturasi dikemukakan oleh d [13] memusatkan perhatian pada praktik sosial yang berulang itu pada dasarnya adalah sebuah teori yang menghubungkan antara agen dan struktur. Seluruh tindakan sosial memerlukan struktur dan seluruh struktur memerlukan tindakam sosial. Agen dan struktur saling menjalin tanpa terpisahkan dalam praktik atau aktivitas manusia.

Teori yang dikemukakan oleh [13] tersebut dapat dijelaskan bahwa titik tolak analisis Giddens adalah praktik atau tindakan manusia, namun tindakan itu dapat dilihat sebagai perulangan. Artinya, aktivitas "bukanlah dihasilkan sekali jadi oleh aktor sosial, tetapi secara terus menerus mereka ciptakan-ulang melalui suatu cara, dan dengan cara itu juga mereka menyatakan diri mereka sendiri sebagai aktor. Melalui aktivitas mereka, agen menciptakan kondisi yang memungkinkan aktivitas ini berlangsung" [13]. Sistem sosial yang berjarak dilihat dari sudut waktu dan ruang seperti itu dalam kehidupan modern makin meningkat peluangnya dengan munculnya penggunaan peralatan komunikasi dan transportasi baru [14]. 
Mengacu pada teori strukturasi tersebut, dapat jelaskan bahwa gaya hidup merupakan sebuah tindakan sosial yang dilakukan oleh agen/ aktor sosial (manusia) secara berulang-ulang dan direalisasikan dalam praktik sosial atau aktivitas sehari- hari dengan memanfaatkan waktu dan ruang. Gaya hidup mahasiswa IAIN Kudus dapat dilihat dari tindakan atau aktivitas mereka dalam memanfaatkan media sosial berupa online shop untuk menghabiskan waktunya sehari-hari. Penggunaan teori strukturasi pada penelitian ini adalah sebagai landasan untuk menjawab dan menganalisis rumusan masalah mengenai gaya hidup mahasiswa IAIN Kudus akibat adanya online shop.

\section{Teori Masyarakat Konsumsi}

Teori masyarakat konsumsi ini merupakan konsep kunci dalam pemikiran Jean Baudrillard untuk menunjukkan gejala konsumerisme yang sangat luar biasa dan telah menjadi bagian dari gaya hidup manusia modern. Baudrillard menyatakan bahwa masyarakat konsumsi tidak lagi digerakkan oleh kebutuhan dan tuntutan konsumen, melainkan oleh kapasitas produksi yang sangat besar. Rasionalitas konsumsi dalam sistem masyarakat konsumen telah berubah drastis, karena saat ini masyarakat membeli barang bukan hanya sebagai upaya untuk memenuhi kebutuhan (needs), namun lebih sebagai pemenuhan hasrat (desire). Konsumsi melibatkan hasrat, oleh karena itu proses konsumsi bukan hanya sekedar proses ekonomi, melainkan melibatkan proses psikologis [15].

Berdasarkan[16]mengemukakan bahwa satu-satunya objek yang dapat memenuhi hasrat adalah objek hasrat yang muncul secara bawah sadar secara imajiner, dan objek hasrat ini telah menghilang dan mampu mencari subsitusi-subsitusinya dalam dunia objek dari simbol-simbol yang dikonsumsi. Banyak orang yang lebih suka membeli "merek", daripada manfaat yang dibelinya, karena merek tersebut sekaligus membawa status bagi orang yang memakainya. Inilah yang dimaksud Baudrillard dengan "orang lebih suka mengonsumsi 'tanda' daripada nilai guna barang yang dikonsumsinya". Bila pada awalnya konsumsi dimaknai sebagai "sebuah proses pemenuhan kebutuhan pokok manusia", namun kemudian konsumsi dialihfungsikan sebagai sarana mengekspresikan posisi seseorang dan identitas kultural seseorang di dalam masyarakat, yang dikonsumsi tidak sekedar objek atau barang, namun juga makna-makna sosial yang tersembunyi dibaliknya konsumsi telah beralih makna menjadi "suatu proses menghabiskan atau mentransformasikan nilai-nilai yang tersimpan dalam sebuah barang", dalam [17].

Perilaku konsumen merupakan proses yang dinamis yang mencakup perilaku konsumen individu, kelompok, dan anggota masyarakat yang secara terus menerus mengalami perubahan [2]. Perilaku konsumen tersebut dapat dijelaskan bahwa seseorang (individu), kelompok, dan anggota kelompok yang melakukan kegiatan ekonomi dengan memanfaatkan barang atau jasa untuk memenuhi kebutuhannya, kegiatan tersebut dilakukan secara terus menerus dari waktu ke waktu hingga mengalami perubahan. Perubahan ini bisa dilihat dari gaya hidup seseorang, khususnya gaya hidup mahasiswa IAIN Kudus akibat adanya teknologi berupa online shop.

Teori masyarakat konsumsi dalam penelitian ini digunakan sebagai 
dasar atau landasan untuk menganalisis pertanyaan dari rumusan masalah mengenai faktor- faktor yang melatarbelakangi mahasiswa IAIN Kudus melakukan pembelian melalui online shop.

\section{METODE PENELITIAN}

Pendekatan yang digunakan dalam penelitian ini adalah metode penelitian kualitatif, yaitu untuk menyajikan dunia sosial, perspektifnya di dalam dunia, dari segi konsep, perilaku, persepsi, dan persoalan tentang manusia yang diteliti. Penelitian ini terfokus pada permasalahan tentang gaya hidup mahasiswa IAIN Kudus akibat adanya online shop dan faktorfaktor yang melatarbelakangi mahasiswa IAIN Kudus melakukan pembelian melalui online shop.

Sumber data penelitian ini berupa informan yang berasal dari mahasiswa IAIN Kudus yang menggunakan jasa online shop, tetapi tidak semua mahasiswa IAIN Kudus melainkan hanya mereka yang memenuhi kebutuhan data dalam penelitian. Sedangkan sumber pendukung informan, diperoleh dari informasi beberapa teman satu kos maupun teman kampus dari pengguna jasa online shop. Teknik pengumpulan datanya dilakukan melalui observasi, wawancara, dan dokumentasi. Sementara itu, untuk menguji keabsahan data dilakukan dengan menggunakan teknik triangulasi sumber. Analisis datanya menggunakan Model Robert C. Bogdan dan Sari Knopp Biklen dengan cara mempersempit fokus penelitian yang kemudian dianalisis dengan membandingkan konsep-konsep yang sudah ada dalam penelitian terdahulu [18].

\section{HASIL DAN PEMBAHASAN}

Perubahan teknologi yang sangat cepat telah memberikan perubahan secara signifikan. Jaringan sosial internet juga dapat mempengaruhi tingkat kebutuhan mahasiswa dalam kehidupannya. Kebutuhan dan kewajiban sebagai mahasiswa pada dasarnya ialah belajar dan menuntut ilmu. Perubahan lingkungan sosial juga tatanan kehidupan, mahasiswa mengubah pola hidupnya sesuai dengan apa yang dikehendaki oleh mahasiswa itu sendiri. Mahasiswa mengekspresikan dirinya dengan mencari informasi terkait dengan tatanan kehidupannya dengan menggunakan teknologi internet. Perkembangan teknologi ini membawa banyak perubahan dalam gaya hidup mahasiswa. Internet memperkenalkan penggunanya kepada dunia maya, beragam fasilitas ditawarkan mulai dari jejaring sosial, berita, video, foto hinga berbelanja dapat ditemukan melalui akses internet. Pemilihan berkonsumsi lahiriah mahasiswa seperti pakaian, tas, sepatu, buku, dan kebutuhan lainnya dapat ditemukan melalui akses internet dengan online shop yang didapatkan dengan mudah.

Penggunaan online shop bagi mahasiswa merupakan perubahan gaya hidup yang semula harus berdesakdesakan di pasar menjadi satu hal yang baru dan praktis. Perubahan tersebut memberikan perubahan nilai sosial, yang semula jika bertransaksi di pasar menggunakan komunikasi secara verbal, sebaliknya jika berbelaja melaui online shop proses transaksinya hanya melalui jaringan internet tanpa bertemu langsung (tatap muka), sehingga tidak adanya proses tawar menawar atau berkomunikasi verbal. Adanya online shop tersebut, telah merubah juga gaya hidup mahasiswa IAIN Kudus. Hal ini 
terlihat dari bentuk perilaku konsumtif di kalangan mahasiswa. Gaya hidup konsumtif pada mahasiswa IAIN Kudus dapat dilihat dari segi penampilan serta cara bergaulnya. Mahasiswa yang memiliki gaya hidup konsumtif selalu berpenampilan menarik, mengenakan fashion bermerk, mengikuti perkembangan zaman dengan cepat, serta memiliki standar hidup menengah ke atas.

Segi penampilan, cara berpakaian mahasiswa tersebut selalu terkesan menarik. Biasanya mereka membeli barang dengan kualitas branded. Mahasiswa yang memiliki gaya hidup konsumtif tidak mau ketinggalan trend, apalagi jika salah satu dari teman mereka sudah memiliki barang terbaru tersebut. Seolah-olah mereka bersaing antara satu dengan yang lainnya demi mendapatkan citra diri yang lebih baik atau setidaknya sama dengan yang lain. Mahasiswa yang bergaya hidup konsumtif menghabiskan banyak waktu untuk melihat barang-barang terbaru melalui internet maupun melihat di online shop sebagai penghilang rasa jenuh, sehingga memiliki kepuasan tersendiri. Sementara itu, mereka lebih banyak bergaul dengan orang-orang yang memiliki hobi yang sama. Pada setiap kesempatan, ketika mereka bertemu pasti membicarakan tentang barang-barang yang lagi trend di online shop, sehingga secara langsung mereka lebih banyak menghabiskan waktu untuk hal-hal yang berhubungan dengan online shop.

Gaya hidup konsumtif yang diperlihatkan mahasiswa karena adanya online shop ini dilakukan berulang-ulang karena mereka selalu update dengan trend yang ada, sehingga secara otomatis pada setiap aktivitas mereka selalu melakukan hal-hal yang berhubungan dengan online shop, baik itu hanya melihat barang-barang di media sosial maupun melakukan transaksi melalui online. Oleh karena itu, online shop sudah menjadi bagian dari aktivitas mereka. Hal ini sejalan dengan teori strukturasi yang dikemukakan oleh Giddens bahwa mahasiswa sebagai agen (aktor sosial) melakukan praktik sosial, dalam hal ini adalah melakukan aktivitas yang berhubungan dengan online shop.

Praktik sosial tersebut dilakukan secara berulang-ulang, sehingga sudah menjadi aktivitas sehari-hari mereka dalam memanfaatkan waktu dan ruang. Waktu dalam arti apakah aktivitas ini dilakukan hanya sementara waktu atau akan terus-menerus sesuai perkembangan zaman yang ada. Pada penelitian ini memperlihatkan bahwa mahasiswa selalu mengikuti trend, berarti selalu mengikuti perkembangan zaman modern berupa penggunaan peralatan komunikasi baru, yaitu memanfaatkan jasa online shop. Sedangkan ruang berarti aktivitas ini berada pada ruang sebagai tempat dimana mahasiswa memanfaatkan jasa online shop, yaitu internet. Selain itu, ruang sebagai ruang sosial mahasiswa dalam melakukan aktivitas yang berhubungan dengan online shop, yaitu berupa kondisi lingkungan sosialnya. Dalam hal ini mahasiswa memperlihatkan mereka lebih banyak bergaul dengan orang yang memiliki hobi sama.

Seseorang dapat dikatakan konsumtif apabila seseorang melakukan atau menjalankan proses konsumsi atau pemakaian barang-barang hasil produksi secara berlebihan atau tidak sepantasnya secara sadar dan berkelanjutan. Hal tersebut menjadikan manusia menjadi pecandu dari suatu produk, sehingga ketergantungan tersebut tidak dapat atau susah untuk 
dihilangkan. Perilaku konsumtif selalu ingin mengikuti perkembangan trend yang ada, sehingga sebisa mungkin mereka segera membeli barang-barang keluaran terbaru. Mereka merasa puas dan senang apabila barang yang diinginkan sudah terbeli, meskipun pada akhirnya barang-barang tersebut tidak mereka butuhkan.

Mahasiswa adalah salah satu pelaku konsumsi dalam pemanfaatan jasa online shop. Mahasiswa menggunakan jasa online shop bukan tanpa sebab, ada faktor pendukung yang menyebabkan mahasiswa menggunakan jasa online shop. Kebutuhan akan berkonsumsi bagi mahasiswa sudah menjadi kebutuhan bukan hanya untuk mengkonsumsi secara manfaat namun konsumsi tatanan nilai baru yang membuat mahasiswa mengkonsumsi barang tersebut. Konsumsi akan runtuh ketika pelaku konsumsi tidak dikelilingi obyek eksternal atau pendukung yang menjadi ekspresi dari kecenderungannya, kekuatannya dan cara pematuhan akan pemenuhan kebutuhan.

Pemikiran mengenai konsumsi masih pada tataran pemenuhan kebutuhan baik barang ataupun jasa, yang didalamnya adanya keikut sertaan keinginan, harapan, tujuan, nilai sosial, efisiensi, kemajuan dan dukungan di sekeliling pelaku kunsumsi (sebagian dari ojek penelitian mengungkapkan bahwa mereka mengkonsumsi online shop karena ada faktor pendukung dari lingkungan). Faktor-faktor yang melatarbelakangi mahasiswa melakukan pembelian melalui online shop adalah sebagai berikut:

1. Efisiensi Waktu

Online shop bagi sebagian mahasiswa memiliki warna baru untuk memenuhi kebutuhan. Keuntungan yang disajikan dalam online shop adalah efisiensi waktu. Menghemat waktu dalam membeli kebutuhan atau berkonsumsi ini dipilih sebagian mahasiswa dalam memanfaatkan online shop.

2. Akses yang Mendukung

Ketika akses mendukung untuk melakukan suatu hal maka sangat mudah untuk mendapatkan apa yang diinginkan. Berbelanja menggunakan jasa online shop lebih mudah, barang yang diinginkan dapat dengan mudah didapatkan dan kita hanya menunggu tanpa harus membeli langsung ke toko. Ketika mahasiswa sudah diberikan fasilitas yang memudahkan untuk mengakses segala yang diinginkan mahasiswa akan memanfaatkannya dengan maksimal. Online shop bisa dikatakan sebagai supermarket elektronik, dimana segala macam kebutuhan yang diinginkan dapat dengan mudah di cari dan didapatkan. Hal itu membuat online shop memiliki tempat sendiri di hati sebagian mahasiswa. Visual yang menarik akan membuat mata dimanjakan oleh tampilan awal barang yang disajikan oleh online shop. Barang yang biasanya sulit ditemukan di toko atau di mall, tetapi melalui online shop dapat di cari dengan mudah.

3. Sebagai Pemenuhan Kebutuhan Bagi sebagian mahasiswa yang tinggal merantau di kota tempat kuliahnya, tentunya memiliki berbagai macam konsumsi yang harus dipenuhi. Konsumsi tersebut menuntut untuk dipenuhi agar terjadi keseimbangan. Namun, saat ini konsumsi yang dimaksud bukan lagi sekedar pemenuhan kebutuhan menurut kajian 
ekonomi yang berarti mengkonsumsi barang sesuai dengan kebutuhan. Tetapi, dari kacamata sosiologis konsumsi yang dimaksud bukan hanya sekedar konsumsi untuk memenuhi kebutuhan atau pemenuhan kebutuhan akan tetapi konsumsi kepuasan dan keinginan. Kaitannya online shop dengan konsumsi keinginan dan pemenuhan kepuasan adalah pada kondisi dimana online shop sebagai alat untuk melancarkan aksi pemenuhan kepuasan. Hal ini dikarenakan jika tidak mengkonsumsi barang lewat online shop, maka ada rasa tidak puas pada dirinya. Konsumsi keinginan disini terbukti oleh beberapa pendapat bahwa online shop dapat memberikan kepuasaan bagi penggunannya. Namun, faktor keinginan disini yaitu memanfaatkan jasa online shop, maka ia sudah mengkonsumsi kebutuhan keinginan.

Online shop merupakan salah satu fasilitas berbelanja di dunia yang disajikan untuk memenuhi kebutuhan manusia. Online shop memberikan warna sendiri bagi pemenuhan berkonsumsi. Online shop pada kenyataanya juga memberikan satu nilai yaitu nilai eksistensi diri di lingkungan sekitar. Konsumsi mengekpresikan posisi sosial dan identitas seseorang dalam kehidupan sosial masyarakat terjadi karena telah banyaknya cara untuk memenuhi kebutuhan akan suatu nilai yaitu gengsi. Konsumsi tidak lagi sekedar objek, tetapi juga makna-makna sosial yang tersembunyi di baliknya. Konsumsi barang tersebut dapat memberikan makna kepada pelaku konsumsi.

Teori masyarakat konsumsi yang dikemukakan oleh Baudrillard sesuai dengan gejala konsumerisme yang terlihat pada gaya hidup mahasiswa yang modern setelah adanya online shop, terbukti mereka tidak mau ketinggalan trend. Hal ini didukung oleh pernyataan tentang faktor-faktor yang melatarbelakangi mahasiswa melakukan pembelian melalui online shop yang berupa efisiensi waktu dan akses yang mendukung. Penggunaan waktu yang singkat dalam melakukan transaksi secara online dan adanya akses untuk terhubung ke internet karena pekembangan zaman, memberikan peluang kepada mahasiswa untuk selalu update dan mengikuti gaya hidup yang modern.

Oleh karena itu, mahasiswa semakin banyak mengkonsumsi barangbarang via online secara berlebihan, sehingga memperlihatkan perilaku konsumtif pada mahasiswa. Selain itu, konsumsi yang dilakukan mahasiswa tidak lagi untuk memenuhi kebutuhan barang, melainkan sudah menjadi pemenuhan kebutuhan psikologis. Hal ini terlihat dari faktor-faktor yang melatarbelakangi mahasiswa melakukan pembelian melalui online shop, yaitu untuk pemenuhan kepuasan. Dengan membeli barang di online shop, mereka akan merasa puas karena barang yang diingankan sudah terbeli.

Pernyataan ini sejalan dengan pendapat [17] bahwa konsumsi melibatkan hasrat, oleh karena itu 
proses konsumsi bukan hanya sekedar proses ekonomi, melainkan melibatkan proses psikologis. Selanjutnya, dengan mengkonsumsi barang di online shop, mahasiswa dapat mengekpresikan posisi sosial dan identitasnya dalam kehidupan sosial di masyarakat.

Sebagian besar mahasiswa melakukanpembelian melalui online shop karena ingin memperlihatkan eksistensinya di lingkungan sosialnya, sehingga mereka cenderung membeli barang bermerk. Inilah yang dimaksud Baudrillard dengan "orang lebih suka mengonsumsi 'tanda' daripada nilai guna barang yang dikonsumsinya". Bila pada awalnya konsumsi dimaknai sebagai "sebuah proses pemenuhan kebutuhan pokok manusia", namun kemudian konsumsi dialihfungsikan sebagai sarana mengekspresikan posisi seseorang dan identitas kultural seseorang di dalam masyarakat, yang dikonsumsi tidak sekedar objek atau barang, namun juga makna- makna sosial yang tersembunyi dibaliknya konsumsi telah beralih makna menjadi suatu proses menghabiskan atau mentransformasikan nilai-nilai yang tersimpan dalam sebuah barang.

Mahasiswa tidak sadar bahwa konsumsi yang dilakukan adalah pola pembentukan yang dirancang oleh para produsen yang pada saat ini adalah adanya kelimpahan barang dan jasa juga suatu pola perubahan cara mengkonsumsi barang dan jasa. Bukan hanya sekedar untuk memenuhi kebutuhan yang seharusnya memiliki nilai fungsi namun ada nilai yang di usung dari tindakan konsumsi yaitu konsumsi nilai kepuasan dan kesenangan.

\section{SIMPULAN}

Online shop telah merubah juga gaya hidup mahasiswa, yang terlihat dari perilaku konsumtif. Gaya hidup konsumtif pada mahasiswa segi penampilan serta cara bergaulnya. Mahasiswa yang memiliki gaya hidup konsumtif selalu berpenampilan menarik, mengenakan fashion bermerk, mengikuti perkembangan zaman dengan cepat, serta memiliki standar hidup menengah ke atas. Selain itu, mereka lebih banyak bergaul dengan orang-orang yang memiliki hobi yang sama. Adapun faktor-faktor yang melatarbelakangi mahasiswa melakukan pembelian melalui online shop adalah karena efisiensi waktu, akses yang mendukung dalam pembelian barang melalui online shop, serta sebagai pemenuhan kebutuhan, baik pemenuhan barang maupun pemenuhan kepuasan.

\section{REKOMENDASI}

Hal yang harus diperhatikan oleh pembaca adalah kita memang perlu mengikuti perkembangan zaman, tetapi jangan sampai terpengaruh dengan halhal yang menjerumuskan pada perilaku negatif, khususnya perilaku konsumtif. Mahasiswa yang cenderung memilih online shop dalam memenuhi kebutuhan, seharusnya selalu mepertimbangkan apa yang ingin dibeli. Pembelian harus dilakukan sesuai dengan kebutuhan yang memang benar-benar dibutuhkan, jangan terpengaruh dengan produk-produk online shop yang tidak dibutuhkan, sehingga perilaku konsumtif dapat dihindari. 
DAFTAR PUSTAKA

[1] L. D. Farida, "Pengukuran User Experience Dengan Pendekatan Usability (Studi Kasus: Website Pariwisata Di Asia Tenggara)," EMNASTEKNOMEDIA ONLINE, vol. 4, no. 1, pp. 1-3, 2016.

[2] T. Suryani, Perilaku Konsumen di Era Internet. Yogyakarta: Graha Ilmu, 2013.

[3] Kominfo.go.id, Diakses pada tanggal 16 Juli 2017 jam 08.15 WIB. .

[4] N. Setiadi, Perilaku Konsumen. Jakarta: Prenada Media, 2005.

[5] M. E. Fitria, "Dampak Online Shop di Instagram dalam Perubahan Gaya Hidup Konsumtif Perempuan Shopaholic di Samarinda," J. Ilmu Sos. dan Ilmu Polit., vol. 3, no. 1, pp. 125-126, 2015.

[6] M. Siska, "Perilaku Sosial: JualBeli Online di Komunitas Mahasiswi Tinjauan Teori Pertukaran Sosial (Social Exchange Theory) oleh George Homans," J. Univ. Tanjungpura Pontianak, vol. 3, no. 4, pp. 5-7, 2016.

[7] A. Kara, "Pengaruh Promosi Penjualan Pakaian Online Shop Elevenia di Bbm Grup terhadap Minat Beli Mahasiswi," J. Ilmu Sos. dan Polit. Univ. Tribuwana Tunggadewi Malang, vol. 5, no. 1, pp. 47-48, 2016.

[8] A. Praja, D.\& Damayantie, "Potret Gaya Hidup Hedonisme di Kalangan Mahasiswa (Studi pada Mahasiswa Sosiologi Fisip Universitas Lampung)," Jurnal. Sosiol. Univ. Lampung, vol. 1, no. 3, pp. 192-193, 2011.

[9] R. Anugrahati, S. \& Dwi, "Gaya Hidup Shopaholic sebagai Bentuk Perilaku Konsumtif pada
Kalangan Mahasiswa Universitas Negeri Yogyakarta," 2014.

[10] dkk Wahyuni, "Gaya Hidup Remaja Kelas Menengah Kota Pekalongan," J. Educ. Soc. Stud., vol. 5, no. 1, pp. 1-7, 2016.

[11] N. R. Diana, "Gaya Hidup Konsumtif Mahasiswa Fakultas Ilmu Sosial dan Hukum Unesa Akibat Adanya Online Shop Jilbab," J. Ilmu Sos. dan Huk., vol. 2, no. 4, pp. 691-692, 2016.

[12] B. Tamam, "Peningkatan Ecoliteracy siswa sebagai Green Consumer melalui Pemanfaatan Kemasan Produk Konsumsi dalam Pembelajaran IPS," J. Pendidik. Ilmu Sos., vol. 24, no. 2, pp. 227238, 2013.

[13] G. dan G. Ritzer, Teori Sosiologi Modern. Jakarta: Kencana Prenada Media Group, 2008.

[14] Y. M. Sari, "Pembinaan toleransi dan peduli sosial dalam upaya memantapkan watak kewarganegaraan (civic disposition) siswa," J. Pendidik. Ilmu Sos., vol. 23, no. 1, 2014.

[15] S. Asyafiq, "Strategi Pertumbuhan dan Pembangunan Ekonomi Di Era Global Berbasis Pendidikan Ekonomi Kewarganegaraan," J. Pendidik. Ilmu Sos., vol. 28, no. 1, pp. 18-30, 2019.

[16] Y. A. Tabrani, P., Himawijaya, \& Piliang, "Kreativitas \& humanitas: sebuah studi tentang peranan kreativitas dalam perikehidupan manusia," Jalasutra, 2006.

[17] N. Martono, Sosiologi Perubahan Sosial. Jakarta: PT Raja Grafindo Persada, 2011.

[18] Emzir, Metodologi Penelitian Kualitatif, Analisis Data. Raja Grafindo Persada., 2010. 